\title{
Effect of Spray with Some Growth Stimulants on Growth, Productivity and Quality of Pepper Grown Under Low Temperature
}

Badr $^{1}$, L. A., M. H. M. Mohamed ${ }^{1}$, M.A. Mady ${ }^{2}$ and A. N. Basha ${ }^{1}$

${ }^{1}$ Horticulture Dept., Fac. Of Agric., Benha University

${ }^{2}$ plant Dept., Fac. Of Agric., Benha University

Corresponding author: asmaanaserr@gmail.com

\begin{abstract}
Two field experiments were carring out during the two successive early summer seasons of 2017 and 2018 at the farm of the Department of Horticulture, Faculty of Agriculture in Mashtoor, Benha University, Qalyubia Governorate to study the effect of soil addition of effective microorganisms (EM) and foliar spraying with salicylic acid, urea phosphate and seaweed extract individual or in combinations on Vegetative growth characteristics, photosynthesis characteristics (chlorophyll a, b, and carotenoids), chemical composition, total yield, and quality characteristics of sweet pepper (Capsicum Annuum,L. California Wonder.)

The experiment included 14 treatments, which are as follows: the effect of beneficial microorganisms (EM) at a concentration of $100 \mathrm{ml} /$ liter seaweed extract at a concentration of 1 and 2 grams / liter, salicylic acid at a concentration of 100 and $200 \mathrm{ppm} /$ liter, urea phosphate at a concentration of 2 and 4 Gram / liter, in addition to the control treatment (without spraying). The obtained results indicated that the highest values in vegetative growth characteristics, photosynthesis characteristics (chlorophyll a, b and carotenoids), chemical composition, total yield, and quality characteristics of sweet pepper fruits were obtained as a result of adding microorganisms. The beneficial (EM) at a concentration of $100 \mathrm{ml} /$ liter as a soil addition with spraying pepper plants with urea phosphate at a concentration of $4 \mathrm{~g}$ / liter three times during the growing season, starting after 20 days of seedlings and once every 20 days in order to improve vegetative growth and increase productivity under conditions of low temperatures in the open field.
\end{abstract}

Keywords: microorganisms, salicylic acid, seaweed extract, urea phosphate

\section{Introduction}

Sweet pepper (Capsicum annuum, L.) is one of the most economic fruit-vegetables species of Family Solanaceae. It is considered one of the most important vegetables grown in Egypt. Sweet pepper is cultivated in Egypt all over the year, out door in summer and indoor (either in greenhouses or in tunnels) in winter season. It is one of warm requiring vegetable crops and it does not tolerate either cooler or frosty weathers during germination and different stages of growth and development without indoor protection. The exposure of chilling-sensitive plants to low temperature causes disturbances in all physiological processes as water regime, mineral nutrition, photosynthesis, respiration and metabolism. (Wien 1997).

Low temperature represents the main adverse factor for production of sweet pepper in winter and early summer plantings under open field conditions . Accordingly, there is a gap between production and consumption of sweet pepper fruits in the Egyptian market during these periods. So, great attention has been focused on the possibility to improve the ability of vegetables to tolerate cold stress.

On the other hand, it was demonstrated that all environment stresses, cold, heat, salt, etc., either accelerate the formation of toxic oxygen free radicals ROS (reactive oxygen species) levels within plant tissues or impair the normal defense mechanisms that protect tissues from ROS toxic effect. Such stresses induce higher $\mathrm{O}_{2}$ photo- reduction within chloroplasts or electron transport disturbance, and donation of an electron to $\mathrm{O}_{2}$ within mitochondria all led to the generation of toxic ROS (Mackersie et al., 1996 ). Those $\operatorname{ROS}\left(\mathrm{H}_{2} \mathrm{O}_{2} \mathrm{OH}, \mathrm{O}_{2} \ldots\right.$ ) damaged chloroplast, reduced carbohydrates synthesis and exportation and hastened oxygen senescence (Dickinson et al., 1991 ), attacked cell membranes leading to their degradation and leakage of cell solutes, denaturation of protein and enzymes, damage of nucleic acids, degradation of

Chlorophyl1 and suppression of all metabolic processes, finally senescence and death of cells and tissues ( Cakmak and Marschner, 1992).

Sweet pepper production is limited by many environmental factors and the cultivar. Many investigators tried to increase the productivity of sweet pepper fruits with high quality and good storability is considered as an important aim that could be achieved through using some bio-stimulants,i.e., effective microorganisms (EM), seaweed extract (SWE) as well as salicylic acid (SA) and urea phosphate ( UP )

(Hamza,2011, Mady, 2014 and Sabra, 2019) .

Effective microorganism(EM) is an organic fertilizer used for soil application to promote growth and increase yield, and is made from a solution of EM and molasses, usually added to bran or straw and then fermented. It has been shown that the application of EM can improve photosynthetic efficiency and capacity due to an increase in nutrient availability, as well as increase root mass (Lindani and Bvenura 
2012). Use of the microorganisms as soil addition, which should improve physical-chemical and biological properties and increase soil organic matter, cation exchange capacity, available mineral nutrients as environment friendly biofertilizer helps to reduce the use of much expensive phosphatic fertilizers (Sabra,2019 and Hamza,2011).

Worldwide, seaweed-based agricultural products are commonly employed (Rosalba, 2013), in organic or reduced-input cropping systems. Seaweed extract are known as a source of plant growth regulators (Herrera et al.,2014) organic osmolites, amino acids mineral nutrients, vitamins and vitamin precursors (Sutharsan et al.,2014,Zewil,2014)

Salicylic acid (SA), is a phenolic compound and considers a phytohormone. It plays an important role in regulation of plant growth and development such as seed germination, photosynthetic and growth rate, flowering, fruit set and fruit ripening ( Mady, 2014).

Furthermore, several studies demonstrated that SA also participates in the signaling of abiotic stress responses, such as drought, high and low temperature, salinity, ozone, UV radiation, and heavy metals. In this respect, Janda et al., 2007 and Horvath et al., 2007, reported that SA enhanced abiotic stress tolerance of various species. This enhanced tolerance was accompanied by increased activities of certain antioxide dismutase . The effect of SA application depends on numerous factors such as the species and developmental stage of the plant, the mode of application, and the concentration of applied and endogenous SA levels (Yun et al,. 2010 )

The use of Urea phosphate(UP) as high soluble $\mathrm{P}$ fertilizer, Phosphorus (P) is an essential macronutrient that can limit normal plant as it constitutes about $0.2 \%$ of plant dry weight. Phosphorus is considered as an integral part of the cellular activities of living organisms and contributes to several vital functions in the plant, such as early root and seedling growth, improving winter hardiness, promotion of early heading and uniform maturity, increasing seed formation and quality, and increasing water-use efficiency. Moreover, it is involved in many plant functions, including storage and transfer of energy, cell division, photosynthesis, transformation of sugars and starches, regulation of some enzymes, nutrient transport within the plant, transport of carbohydrates, and transfer of genetic characteristics from one generation to another.

The present study aimed to alleviate the adverse effects of low temperature and its probable accompanied oxidative stress on sweet pepper plants towards improving their growth and productivity during winter months by using Seaweed extract (SWE) ,Microorganisms (EM), Salicylic acid (SA) and Urea phosphate.

\section{Materials and Methods}

Two field experiments were carried out during the two successive early summer seasons of 2017 and 2018 in the Experimental farm at Horticulture Dept., Faculty of Agri., Benha University ,Kalubia Governorate, to investigate the effect of soil addition of effective microorganisms (EM) and the foliar spray with salicylic acid (SA), urea phosphate (UP) and seaweed extract (SWE) individual or in combinations on growth, chemical composition, fruit yield and its quality of sweet pepper (capsicum annuиm, L. California wonder.) plants.

Mechanical and chemical analyses of experimental soil are presented in Table (1). according to Jackson (1973) and Black et al .(1982).

Table 1. Mechanical and chemical analyses of the experimental soil in the two seasons 2017 and 2018. Mechanical analysis

\begin{tabular}{|c|c|c|c|}
\hline Soil particles & Unit & \multicolumn{2}{|c|}{ Seasons } \\
\hline & & 2017 & 2018 \\
\hline Coarse sand & $\%$ & 15.20 & 15.40 \\
\hline Fine sand & $\%$ & 13.50 & 13.70 \\
\hline Silt & $\%$ & 16.62 & 16.40 \\
\hline Clay & $\%$ & 54.88 & 54.50 \\
\hline Textural & $\%$ & Clay & Clay \\
\hline \multicolumn{4}{|l|}{ Chemical analysis } \\
\hline \multirow[t]{2}{*}{ Parameters } & \multirow[t]{2}{*}{ Unit } & \multicolumn{2}{|c|}{ Seasons } \\
\hline & & 2017 & 2018 \\
\hline Organic matter & $\%$ & 1.57 & 2.33 \\
\hline Available N & ppm & 63.4 & 65.3 \\
\hline Available P & ppm & 7.4 & 7.6 \\
\hline Available K & ppm & 27.5 & 26.7 \\
\hline $\mathrm{CaCo3}$ & $\%$ & 0.55 & 0.57 \\
\hline Iron & ppm & 24.8 & 25.0 \\
\hline Zinc & ppm & 4.27 & 4.75 \\
\hline Manganese & ppm & 14.6 & 15.70 \\
\hline Copper & ppm & 2.87 & 2.54 \\
\hline Boron & ppm & 12.0 & 14.0 \\
\hline $\mathbf{p H}$ & & 7.76 & 7.48 \\
\hline
\end{tabular}


Table (2): Monthly average air temperature and relative humidity in Moshtohor - Qalyobia Governorate during two seasons of the experimental 2017-2018

\begin{tabular}{|c|c|c|c|c|c|c|c|}
\hline \multicolumn{2}{|c|}{ MONTHS } & \multicolumn{3}{|c|}{2017} & \multicolumn{3}{|c|}{2018} \\
\hline & & \multicolumn{2}{|c|}{ Temperature ${ }^{\circ} \mathrm{C}$} & \multirow{2}{*}{$\frac{\text { R.H\% }}{\text { Average }}$} & \multicolumn{2}{|c|}{ Temperature ${ }^{\circ} \mathrm{C}$} & \multirow{2}{*}{$\begin{array}{c}\text { R.H\% } \\
\text { Average }\end{array}$} \\
\hline & Day & $\operatorname{Max}$ & Min & & Max & Min & \\
\hline & 1:10 & 14.15 & 6.43 & 66.24 & 18.29 & 7.49 & 64.41 \\
\hline \multirow[t]{3}{*}{ January } & 10:20 & 17.93 & 7.8 & 67.67 & 19.89 & 7.60 & 64.01 \\
\hline & $20: 30$ & 20.89 & 10.52 & 61.80 & 15.06 & 4.48 & 72.27 \\
\hline & 1:10 & 21.58 & 8.72 & 59.58 & 20.02 & 7.35 & 65.43 \\
\hline \multirow[t]{3}{*}{ February } & $10: 20$ & 15.25 & 6.21 & 69.44 & 26.10 & 10.99 & 54.79 \\
\hline & $20: 28$ & 20.92 & 9.90 & 64.05 & 24.08 & 11.05 & 61.06 \\
\hline & 1:10 & 22.54 & 10.08 & 66.69 & 26.28 & 12.39 & 55.02 \\
\hline \multirow[t]{3}{*}{ March } & 10:20 & 21.27 & 9.27 & 66.64 & 26.51 & 13.85 & 52.61 \\
\hline & $20: 30$ & 23.88 & 12.08 & 62.68 & 26.56 & 13.31 & 55.12 \\
\hline & 1:10 & 24.41 & 11.94 & 63.67 & 29.96 & 13.69 & 50.60 \\
\hline \multirow[t]{3}{*}{ April } & $10: 20$ & 23.06 & 10.25 & 64.67 & 29.97 & 16.14 & 55.19 \\
\hline & $20: 30$ & 26.61 & 12.51 & 61.37 & 34.48 & 18.35 & 48.86 \\
\hline & $1: 10$ & 27.51 & 14.35 & 66.38 & 32.74 & 17.76 & 49.72 \\
\hline \multirow[t]{3}{*}{ May } & 10:20 & 28.74 & 16.24 & 64.37 & 34.89 & 19.32 & 48.42 \\
\hline & $20: 30$ & 31.05 & 18.77 & 62.03 & 34.88 & 19.66 & 51.25 \\
\hline & $1: 10$ & 29.62 & 17.73 & 64.01 & 36.78 & 21.96 & 49.12 \\
\hline \multirow[t]{2}{*}{ June } & $10: 20$ & 30.26 & 19.74 & 66.78 & 36.50 & 22.31 & 55.63 \\
\hline & $20: 30$ & 30.1 & 19.28 & 65.26 & 35.09 & 23.08 & 59.36 \\
\hline
\end{tabular}

\section{-Climatological data:}

Air temperature and relative humidity during two growing seasons (2017-2018) are reported in table (2) maximum and minimum air temperature and humidity were recorded after Shebeen El-Kanater weather station.

The area of the experimental plot was $11,2 \mathrm{~m}^{2}$ included one bed each 4 meters in long and 70 centemeters in width. Transplanting was done on one side of ridge at $30 \mathrm{~cm}$ apart between transplants. Transplanting was done on $1^{\text {st }}$ February in both seasons of 2017 and 2018, respectively. All agriculture practices were done as recommended by Ministry of Agriculture for a good production of pepper.

This experiment included 14 treatments resulted from the combination between one soil additions treatments and three spray treatments as follows.

\section{3-1- Soil addition treatment:}

1- Effective microorganisms (EM) at 100ml/L.

3-2- Foliar spray treatments:

1- Seaweed extract(SWE) at $1 \mathrm{~g} / 1$.

2- Seaweed extract(SWE) at $2 \mathrm{~g} / 1$.

3-Salicylic acid (SA) at $100 \mathrm{ppm} / \mathrm{l}$.

4-Salicylic acid (SA) at $200 \mathrm{ppm} / 1$.

5-Ureaphosphate (UP) at $2 \mathrm{~g} / 1$.

6-Ureaphosphate (UP) $4 \mathrm{~g} / \mathrm{l}$.

7-The control treatment (spray with distilled water).

Effective microorganisms : ( EM as commercial name) was obtained from Ministry of Agriculture and Land Reclamation it includes: Effective Microorganisms (EM) preparation contains photosynthetic bacteria (Rhodopseudomonas palustrus and Rhodobacter space), milk bacteria (Lactobacillus casei, Streptococcus lactis), yeast (Saccharomyces albus and Candida utilis), actinomycetes (Streptomyces albus and Streptomyces griseus) and moulds (Aspergillus oryzae and Mucom hiemalis) Allahverdiyev et al. (2011).

Seaweed extract :Organic matter 58,2\%, Nitrogin $1 \%$, Potassioum 20,43\% ,Phosphours 3,52\% , alginic acid $19,3 \%$ from TechnoGene, Eldokki -Giza-Egypt. Salicylic acid treatments: A certain weight $(1 \mathrm{~g})$ of salicylic acid was solved in $100 \mathrm{ml}$ of $85 \%$ of methanol then completed with distilled water to one litter to make up stock solution of salicylic acid at concentration $1000 \mathrm{ppm}$. Then 100 and $200 \mathrm{ml}$ of stock solution were separately taken and completed with distilled water to one liter for preparing, the applied concentrations of salicylic acid, i.e., 100 and 200 ppm, respectively.

Effective Ureaphosphate (magnum):

(Ureaphosphate(17-44-0) as commercial name ) was obtained from Smart Nile for Agricultural Development, Al Zohor Tower - Quesna - Menoufiya - Egypt .

Experimental design:

A split plot design with three replicates was used in this experiment where the soil addition treatments were distributed in the main plots while the spray treatments were located randomly in the sub plots. The agricultural practices concerning cultivation, fertilization, irrigation, insect and disease control were conducted as commonly followed according to the recommendation of the ministry of 
Agriculture for the commercial production of sweet pepper.

Data on vegetative growth, yield and its components, and physical and chemical fruits characteristics were recorded as follows:

\section{3-3- Sampling and collecting data:}

3-3-1- Vegetative growth characteristics.

Different morphological characteristics of sweet pepper plants at 65 days after transplanting (i.e.the time of start in both flowering and fruiting ).were measured and/or calculated three plants from each treatment were randomly taken for measurements.

The following characteristics were inspected :

1-Plant height $(\mathrm{cm})$.

2-Stem diameter $(\mathrm{cm})$.

3-Stems fresh weight $(\mathrm{g}) /$ plant.

4-Leaves fresh weight $(\mathrm{g}) /$ plant.

5-Shoots fresh weight $(\mathrm{g}) /$ plant .

6-Number of branches/plant.

7-Number of leaves/plant.

8- Total Leaf area/plant using the disk method according to Derieux et al.(1973).

9- Leaf area ratio (L.A.R) is defined as the ratio of assimilatory material per unit of plant material percent, according to Radford (1967).

$$
\text { LAR }=\frac{\text { Leaf area } / \text { plant }\left(\mathrm{cm}^{2}\right)}{\text { Total shoots dryweight } / \text { plant }(\mathrm{gm})}
$$

10-Specific leaf weight (S.L.W) according to Hall $\boldsymbol{e t}$ al. (1993).

$$
\mathrm{SLW}=\frac{\text { Dry weight of leaves }(\mathrm{mg})}{\text { leaf area } / \text { plant }\left(\mathrm{cm}^{2}\right)}
$$

\section{3-3-2 : Flowering and fruiting characteristics:}

for studying the flowering behavior of the various treatments in sweet pepper, four plants per each treatment were randomly taken, labeled and following data were recorded :

\section{1- Start of flower anthesis (days):}

Number of days passed from transplanting till anthesis of the first flower in sweet pepper.

\section{2 - Number of flowers /plant:}

The total number of the opened flowers per plant through the season were recorded for each treatment of sweet pepper plants.

\section{3-Number of total fruits /plant :}

The number of all harvested fruits per each treatment divided by the number of plants in the same treatment

\section{4-Total yield (kg)/plant:}

The fresh weight of all harvested fruits per treatment divided by the number of plants in the same treatment

\section{5-Relative total yield \%:}

Total yield of each treatment was calculated as a percentage of control.

6-Average fruit weight (gm):

The weight of all harvested fruits per plant divided by the number of fruits per plant .

7-Average fruvit dry weight (gm):

The dry weight of all harvested fruits per plant divided by the number of fruits per plant .

\section{8-Fruit diameter $(\mathbf{c m})$ :}

This trait was expressed as the mean diameter in $\mathrm{cm}$ using 10 fruits randomly taken per treatment .

9-Fruit length (cm):

It was expressed as the mean length in $\mathrm{cm}$ using 10 fruits randomly taken per treatment .

10- Fruit shape index (L/D):

It was calculated as the ratio between the length and the diameter (L/D) of the fruit .

\section{3-3-3 Statistical analysis:}

Data of vegetative growth, flowering, yield and chemical composition of sweet pepper plants and fruits were subjected to statistical analysis according to Snedecor and Cochran (1989) using L.S.D. test at 0.05 level.

\section{Results and discussion}

\section{Growth behavior}

\section{I.1. Vegetative characteristics}

Data in Table (3) clearly indicate the effect of soil addition of effective microorganisms (EM) and foliar spray with salicylic acid (SA), urea phosphate (UP) and seaweed extract (SWE) individual or in combinations on different estimated characteristics (i.e., plant height, stem diameters and the fresh weight of each of stems and leaves) of sweet pepper in case of all applied treatments were significantly increased when compared with control plants .

These results are of great interest, because at this early stage of growth great stimulative positive difference existed with various applied treatments at open field under low temperature Table (2) .

Since that could be prolonged to the advanced growth stage including each of flowering and the final fruit yield as well as the high quality of yielded fruits.

Meanwhile, plant height, stem diameters stems and leaves fresh weights showed their maximum ( significant ) increase in case of E.M and U P at $4 \mathrm{~g} / \mathrm{l}$ treatment during 2017 and 2018 seasons .

In addition, increment of shoots ( stems and leaves ) fresh weight could be basic for increasing each of leaf area and the photosynthetic efficiency, thereby, more dry matter production and their allocation to fruit being expected .

\section{I.2. Branches and leaves characteristics}

Data in Table (4) show that each of number of branches and leaves, leaf area per plant and the leaves dry weight were increased to reach the high level of significance with different applied treatments during 2017 and 2018 seasons . 
As for the numbers of branches per plant all applied treatments were significantly increased during two seasons. Also, it could be noticed that each of U$P$ treatment at $2 \mathrm{~g} / \mathrm{l}$ and $4 \mathrm{~g} / \mathrm{l}$ with $\mathrm{EM}$ and U-P treatment without EM as well increased thin number more than tow times of the control during 2017 and 2018 seasons. Here the treatment of U-P at $4 \mathrm{~g} / \mathrm{l}$ with EM gave the highest number those reached to 20 and 23 branch per plant during 2017 and 2018 seasons , respectively .

In this respect increasing of formed branches on a growing plant could be reversed upon many other characters such an number of leaves, leaf area, leaves dry weight, flowering and finally the yielded fruits .

With regard to the number of leaves it could be also noticed that nearly behaved an the same an number of branches . Since U-P at $4 \mathrm{~g} / \mathrm{l}$ only or U-P at $4 \mathrm{~g} / \mathrm{l}$ with EM gave the highest values but the U-P at $4 \mathrm{~g} / 1$ with $\mathrm{EM}$ were preceding in this respect, since increase in leaves number reached more than two times of control values in two assigned seasons .
As regards the total leaf area per plant it behaved as the same as the two mentioned characteristics. Since, all applied treatments showed its significant increase but its maximum was also, obtained with the $\mathrm{U}-\mathrm{P}$ at $4 \mathrm{~g} / \mathrm{l}$ only and $\mathrm{U}-\mathrm{P}$ at $4 \mathrm{~g} / \mathrm{l}$ with EM treatments . Increment of leaf area in of great interest because that could be reflected upon the efficiency of photosynthesis by accumulating more assimilates and high rates of their translocation specially toward formed fruits . Also, it could be noticed that increment of this a area was preceded with high number of branches and leaves as well

Regarding leaves dry weight, of interest to note that (Table 4 ) all applied treatments increased it to reach the high level of significance . Also, increment of this weight with U-P at $4 \mathrm{~g} / \mathrm{l}$ only and U-P $4 \mathrm{~g} / \mathrm{l}$ with EM reached more than two times of the control of value . these data go will with the above mentioned possibility for increasing yielded fruits .

Table (3). Effect of EM, growth stimulants and their interaction on some morphological characteristics of sweet pepper 2017-2018 seasons.

\begin{tabular}{|c|c|c|c|c|c|c|c|c|c|c|c|c|}
\hline & Growth character & $\begin{array}{l}\text { reatment } \\
\text { wth }\end{array}$ & \multicolumn{2}{|c|}{$\begin{array}{l}\text { Plant height } \\
(\mathrm{cm})\end{array}$} & \multicolumn{2}{|c|}{$\begin{array}{l}\text { Stem diameter } \\
(\mathrm{cm})\end{array}$} & \multicolumn{2}{|c|}{$\begin{array}{l}\text { Stems fresh } \\
\text { weight } \\
\text { (g)plant }\end{array}$} & \multicolumn{2}{|c|}{$\begin{array}{c}\text { Leaves fresh } \\
\text { weight } \\
\text { (g)/pant }\end{array}$} & \multicolumn{2}{|c|}{$\begin{array}{c}\text { Shoots fresh } \\
\text { weight } \\
\text { (g)/plant }\end{array}$} \\
\hline EM & \multicolumn{2}{|c|}{$\begin{array}{l}\text { Growth } \\
\text { stimulants }\end{array}$} & 2017 & 2018 & 2017 & 2018 & 2017 & 2018 & 2017 & 2018 & 2017 & 2018 \\
\hline \multirow{2}{*}{$\begin{array}{l}\text { With EM } \\
\text { Without } \\
\text { EM }\end{array}$} & & & 26.16 & 26.67 & 1.23 & 1.25 & 19.60 & 21.03 & 58.21 & 63.91 & 77.81 & 84.92 \\
\hline & & & 25.22 & 25.47 & 1.19 & 1.17 & 22.78 & 25.52 & 53.11 & 59.08 & 83.60 & 85.89 \\
\hline \multirow[t]{8}{*}{ L.S.D } & & & 2.20 & 2.23 & 0.22 & 0.24 & 4.92 & 4.96 & 11.80 & 11.86 & 16.55 & 16.82 \\
\hline & \multicolumn{2}{|c|}{ Control } & 22.57 & 22.26 & 0.95 & 0.95 & 13.77 & 14.80 & 30.86 & 37.16 & 44.64 & 51.96 \\
\hline & \multirow{3}{*}{ S.W } & 1 m.L & 24.52 & 24.56 & 1.21 & 1.19 & 16.89 & 18.70 & 43.64 & 50.04 & 87.54 & 68.75 \\
\hline & & 2 m.L & 25.01 & 25.29 & 1.25 & 1.25 & 21.04 & 25.65 & 51.88 & 55.99 & 72.93 & 81.77 \\
\hline & & 2 g.L & 26.36 & 27.13 & 1.28 & 1.28 & 25.15 & 28.33 & 68.34 & 73.01 & 93.50 & 54.85 \\
\hline & $\mathbf{U P}$ & 4 g.L & 28.03 & 28.93 & 1.32 & 1.32 & 30.93 & 34.83 & 78.75 & 84.92 & 109.69 & 119.75 \\
\hline & \multirow[t]{2}{*}{$\mathbf{S A}$} & $\begin{array}{c}100 \\
\text { ppm }\end{array}$ & 26.36 & 26.85 & 1.26 & 1.27 & 18.18 & 20.01 & 53.40 & 58.99 & 71.59 & 78.50 \\
\hline & & $\begin{array}{c}200 \\
\text { ppm }\end{array}$ & 26.96 & 27.45 & 1.21 & 1.22 & 22.35 & 24.94 & 62.71 & 70.84 & 85.07 & 95.79 \\
\hline L.S.D & & & 2.16 & 2.18 & 0.17 & 0.21 & 4.72 & 4.86 & 11.22 & 11.15 & 16.20 & 16.38 \\
\hline \multirow[t]{7}{*}{ With EM } & \multicolumn{2}{|c|}{ Control } & 22.45 & 22.57 & 1.00 & 1.11 & 12.99 & 13.50 & 34.01 & 41.81 & 47.00 & 55.31 \\
\hline & & 1 m.L & 25.16 & 25.35 & 1.23 & 1.20 & 16.11 & 18.18 & 46.57 & 53.07 & 62.68 & 71.25 \\
\hline & \multirow{2}{*}{ S.W } & $2 \mathrm{~m} . \mathrm{L}$ & 25.36 & 25.78 & 1.27 & 1.28 & 19.23 & 21.84 & 54.16 & 58.27 & 73.39 & 80.10 \\
\hline & & 2 g.L & 27.12 & 27.95 & 1.33 & 1.34 & 21.30 & 23.91 & 72.57 & 75.40 & 93.87 & 99.31 \\
\hline & $\mathbf{U P}$ & 4 g.L & 28.66 & 29.70 & 1.34 & 1.35 & 29.64 & 32.76 & 80.81 & 88.17 & 110.45 & 120.93 \\
\hline & \multirow[t]{2}{*}{ SA } & $\begin{array}{c}100 \\
\text { ppm }\end{array}$ & 26.60 & 27.20 & 1.22 & 1.23 & 16.62 & 17.76 & 55.90 & 60.01 & 72.52 & 77.68 \\
\hline & & $\begin{array}{r}200 \\
\text { ppm } \\
\end{array}$ & 27.75 & 28.15 & 1.24 & 1.25 & 21.30 & 19.23 & 63.47 & 70.62 & 84.77 & 89.85 \\
\hline \multirow{7}{*}{$\begin{array}{l}\text { Without } \\
\text { EM }\end{array}$} & \multicolumn{2}{|c|}{ Control } & 22.70 & 21.95 & 0.90 & 0.80 & 14.55 & 16.11 & 27.72 & 32.50 & 42.27 & 48.61 \\
\hline & & 1 m.L & 23.88 & 23.78 & 1.20 & 1.18 & 17.67 & 19.23 & 40.72 & 47.01 & 112.39 & 66.24 \\
\hline & \multirow[t]{2}{*}{ S.W } & 2 m.L & 24.66 & 24.80 & 1.23 & 1.22 & 22.86 & 29.64 & 49.61 & 53.72 & 72.47 & 83.36 \\
\hline & & 2 g.L & 25.60 & 26.32 & 1.24 & 1.23 & 29.01 & 23.76 & 64.12 & 70.62 & 93.13 & 103.38 \\
\hline & $\mathbf{U P}$ & 4 g.L & 27.40 & 28.16 & 1.30 & 1.29 & 32.22 & 36.90 & 76.70 & 81.67 & 108.92 & 118.57 \\
\hline & \multirow[t]{2}{*}{ SA } & $\begin{array}{c}100 \\
\text { ppm }\end{array}$ & 26.10 & 26.50 & 1.30 & 1.31 & 19.75 & 22.35 & 50.91 & 56.97 & 70.66 & 79.32 \\
\hline & & $\begin{array}{c}200 \\
\text { ppm } \\
\end{array}$ & 26.18 & 26.75 & 1.18 & 1.19 & 23.40 & 30.66 & 61.96 & 71.06 & 85.36 & 101.72 \\
\hline L.S.D & & & 2.11 & 2.13 & 0.12 & 0.13 & 4.25 & 4.65 & 11.20 & 11.13 & 15.70 & 15.88 \\
\hline
\end{tabular}

Moreover, the calculated data of each of leaf area ratio and specific leaf weight could be support the above mentioned data about the vigorous growth of sweet pepper plants grown at low temperature in open field when treated with S.W , U-P and SA individual or in combination with E.M. treatments . 


\section{I.3 Dry matter distribution:}

Data presented in Table ( 5 ) indicate the effect of soil addition of ( EM ) and the foliar spray with SA , UP and SWE individual or in combination on dry matter production and distribution in branches ( including the main stem ) and leaves of sweet pepper at 65 days after transplanting. Data clearly indicated that different combination treatment EM with SA, UP and SWE increased dry weight of branches at this early stage of growth . Also, the UP at $4 \mathrm{~g} / \mathrm{l}$ with EM treatment gave the highest value during 2017 and 2018 seasons .

As for leaves dry weight, data in Table ( 5 ) evidently confirmed the stimulatory effects of applied combination treatments upon dry matter production

Table 4. Effect of EM, growth stimulants and their interaction on branches and leaf characteristics of sweet pepper plants during 2017-2018 seasons.

\begin{tabular}{|c|c|c|c|c|c|c|c|c|c|c|c|c|c|c|}
\hline \multirow{2}{*}{$\begin{array}{c}\text { Growth Character } \\
\text { EM }\end{array}$} & \multicolumn{2}{|c|}{ Treatments } & \multicolumn{2}{|c|}{$\begin{array}{c}\text { No. of } \\
\text { branches/plant }\end{array}$} & \multicolumn{2}{|c|}{$\begin{array}{c}\text { No. of } \\
\text { leaves/plant }\end{array}$} & \multicolumn{2}{|c|}{$\begin{array}{l}\text { Leaf area/ plant } \\
\qquad\left(\mathrm{cm}^{2}\right)\end{array}$} & \multicolumn{2}{|c|}{$\begin{array}{l}\text { Leaves dry weight } \\
(\mathrm{g}) / \mathrm{plant}\end{array}$} & \multicolumn{2}{|c|}{$\begin{array}{l}\text { Leaf area ratio } \\
\text { (L.A.R) } \\
\left(\mathrm{cm}^{2} / \mathrm{g}\right)\end{array}$} & \multicolumn{2}{|c|}{$\begin{array}{l}\text { Specific leaf weight } \\
\qquad \begin{array}{c}\text { (S.L.W) } \\
\left(\mathrm{mg} / \mathrm{cm}^{2}\right)\end{array}\end{array}$} \\
\hline & \multicolumn{2}{|c|}{ Growth stimulants } & 2017 & 2018 & 2017 & 2018 & 2017 & 2018 & 2017 & 2018 & 2017 & 2018 & 2017 & 2018 \\
\hline \multirow{10}{*}{$\begin{array}{c}\text { With EM } \\
\text { Without EM } \\
\text { L.S.D }\end{array}$} & & & 14.61 & 15.62 & 89.57 & 99.61 & 589.35 & 647.00 & 8.06 & 8.84 & 54.63 & 61.18 & 20.60 & 22.62 \\
\hline & & & 12.52 & 13.47 & 81.71 & 90.90 & 537.65 & 623.50 & 7.35 & 8.17 & 49.70 & 55.45 & 18.82 & \\
\hline & & & 5.84 & 5.92 & 12.60 & 12.84 & 142.67 & 142.96 & 3.62 & 3.74 & 9.66 & 9.72 & 3.62 & 3.86 \\
\hline & \multicolumn{2}{|c|}{ Control } & 8.83 & 9.50 & 47.50 & 57.17 & 312.52 & 376.15 & 4.28 & 5.14 & 28.97 & 34.87 & 10.93 & 13.15 \\
\hline & \multirow[t]{2}{*}{ S.w } & $1 \mathrm{~m} . \mathrm{L}$ & 10.83 & 12.00 & 67.16 & 77.00 & 441.91 & 506.63 & 6.05 & 6.93 & 36.46 & 46.66 & 15.45 & 17.71 \\
\hline & & $2 \mathrm{~m} . \mathrm{L}$ & 13.50 & 16.50 & 57.33 & 86.16 & 525.28 & 566.93 & 7.18 & 7.75 & 48.70 & 52.56 & 18.37 & 19.82 \\
\hline & \multirow[t]{2}{*}{ up } & $2 \mathrm{~g} . \mathrm{L}$ & 16.01 & 18.17 & 105.16 & 112.33 & 691.95 & 739.13 & 9.46 & 10.11 & 63.65 & 68.52 & 24.19 & 25.84 \\
\hline & & $4 \mathrm{~g} . \mathrm{L}$ & 19.83 & 22.33 & 121.17 & 130.66 & 797.27 & 948.57 & 10.90 & 11.75 & 73.91 & 79.70 & 27.87 & 30.05 \\
\hline & \multirow[t]{2}{*}{ SA } & $\begin{array}{l}100 \\
\text { ppm }\end{array}$ & 16.66 & 12.83 & 82.56 & 90.00 & 540.65 & 592.17 & 7.42 & 8.09 & 50.12 & 54.90 & 18.90 & 20.70 \\
\hline & & $\begin{array}{l}200 \\
\mathrm{ppm}\end{array}$ & 14.33 & 16.00 & 96.50 & 109.00 & 634.94 & 717.19 & 8.68 & 9.81 & 58.86 & 66.49 & 22.20 & 25.07 \\
\hline L.S.D & & & 5.40 & 5.70 & 12.22 & 12.36 & 142.62 & 142.82 & 3.35 & 3.42 & 9.59 & 9.62 & 3.42 & 3.46 \\
\hline \multirow{7}{*}{ With EM } & \multicolumn{2}{|c|}{ Control } & 9.33 & 10.33 & 52.33 & 64.33 & 344.33 & 423.29 & 4.71 & 5.78 & 31.92 & 39.24 & 12.04 & 14.80 \\
\hline & S.w & $1 \mathrm{~m} . \mathrm{L}$ & 11.33 & 12.33 & 71.66 & 81.66 & 471.52 & 537.32 & 6.45 & 7.35 & 43.71 & 49.20 & 16.48 & 18.78 \\
\hline & & $2 \mathrm{~m} . \mathrm{L}$ & 14.66 & 19.00 & 83.33 & 98.66 & 548.31 & 589.96 & 7.49 & 8.06 & 50.83 & 54.69 & 19.17 & 20.62 \\
\hline & up & $2 \mathrm{~g} . \mathrm{L}$ & 18.66 & 21.00 & 111.66 & 116.00 & 734.72 & 763.28 & 10.05 & 10.44 & 68.11 & 70.76 & 25.68 & 26.68 \\
\hline & & $4 \mathrm{~g} . \mathrm{L}$ & 20.66 & 23.66 & 124.33 & 135.66 & 818.09 & 892.64 & 11.18 & 12.20 & 75.84 & 82.75 & 28.60 & 31.20 \\
\hline & SA & $\begin{array}{l}100 \\
\text { ppm }\end{array}$ & 12.66 & 14.33 & 86.00 & 92.33 & 565.88 & 607.53 & 7.78 & 8.30 & 52.46 & 65.32 & 19.78 & 21.24 \\
\hline & & $\begin{array}{l}200 \\
\text { ppm }\end{array}$ & 15.00 & 19.66 & 97.66 & 108.66 & 642.60 & 714.98 & 8.78 & 9.78 & 59.57 & 66.28 & 22.46 & 24.99 \\
\hline \multirow{7}{*}{ Without EM } & \multicolumn{2}{|c|}{ Control } & 8.33 & 8.66 & 42.66 & 50.00 & 280.70 & 329.00 & 3.84 & 4.50 & 26.02 & 30.50 & 9.81 & 11.50 \\
\hline & \multirow{2}{*}{ S.w } & $1 \mathrm{~m} . \mathrm{L}$ & 10.33 & 11.66 & 62.66 & 72.33 & 412.30 & 475.93 & 5.64 & 6.50 & 38.22 & 44.12 & 14.41 & 16.64 \\
\hline & & $2 \mathrm{~m} . \mathrm{L}$ & 12.33 & 14.00 & 76.33 & 82.66 & 502.25 & 543.90 & 6.86 & 7.44 & 46.56 & 50.42 & 17.56 & 19.1 \\
\hline & \multirow{2}{*}{ up } & 2 g.L & 13.36 & 15.33 & 98.66 & 108.66 & 649.18 & 714.98 & 8.87 & 9.78 & 59.19 & 66.28 & 22.69 & 24.99 \\
\hline & & $4 \mathrm{~g} . \mathrm{L}$ & 19.00 & 21.00 & 118.00 & 125.66 & 776.44 & 1004.50 & 10.62 & 11.30 & 71.98 & 76.65 & 27.14 & 28.90 \\
\hline & \multirow{2}{*}{ SA } & $\begin{array}{l}100 \\
\text { ppm }\end{array}$ & 10.66 & 11.33 & 78.33 & 87.66 & 515.41 & 576.80 & 7.05 & 7.88 & 47.78 & 53.47 & 18.2 & 20.16 \\
\hline & & $\begin{array}{r}200 \\
\text { ppm }\end{array}$ & 13.66 & 12.33 & 95.33 & 109.33 & 627.27 & 719.39 & 8.58 & 9.84 & 58.15 & 66.69 & 21.93 & 25.15 \\
\hline L.S.D & & & 4.46 & 4.54 & 11.62 & 11.82 & 141.66 & 142.17 & 3.12 & 3.22 & 9.43 & 9.56 & 3.25 & 3.32 \\
\hline
\end{tabular}

In general data in Table ( 5 ) not only being a direct results for that vigorous growth obtained in Table ( 3 , 4 ) but also could be considered an indicator for expectable high yield of fruits .

\section{Reproductive growth:}

In this part of the present study the effect of different applied treatments U-P, S wand SA with or without EM soil addition upon different flowering characteristics, i.e. the start of flowers anthesis and their earliness as well, number of flowers per plant and accumulation in leaves . Also, UP at $4 \mathrm{~g} / \mathrm{l}$ with EM was more pronounced in this respect . therefore, total dry weight of shoots also behaved as the same as branches and leaves with different applied treatments and also with priority of the UP at $4 \mathrm{~g} / \mathrm{l}$ with EM one . Moreover , dry matter distribution was highly significantly affected. Since, more dry matter being distributed into leaves but that also confirm the high efficiency of photosynthesis process in plants grown at low temperature in open field with treated by applied soil addition and foliar spray . Also, The U-P at $4 \mathrm{~g} / \mathrm{l}$ with EM treatment gave the best one when combined with either treatment or control during two seasons . 
and SA opened their flowers earlier than control plants . the most effective treatment in this respect was foliar spray by UP at $4 \mathrm{~g} / \mathrm{l}$ with EM one followed by EM at $4 \mathrm{~g} / \mathrm{l}$ only, AS and SW one ranked the last when compared with control .

Also, it could be noticed that these days of earliness existed with different applied treatments reached to significance during the two seasons. Since , earliness with 81 days could be followed by rapid development and growth of settled fruits their by earliness in repined sweet pepper fruits being expected.

Table 5. Effect of EM, growth stimulants and their interaction on dry matter distribution in different organs of sweet pepper plants during 2017-2018 seasons.

\begin{tabular}{|c|c|c|c|c|c|c|c|c|c|c|c|c|c|c|}
\hline \multirow{3}{*}{$\begin{array}{c}\text { Treatments } \\
\text { EM }\end{array}$} & \multicolumn{2}{|c|}{ Growth character } & \multicolumn{4}{|c|}{$\begin{array}{c}\text { Branches(including main stem) dry } \\
\text { weight }\end{array}$} & \multicolumn{4}{|c|}{ Leaves dry weight } & \multirow{2}{*}{\multicolumn{2}{|c|}{$\begin{array}{l}\text { *Total dry } \\
\text { weight } \\
\text { (g) / plant }\end{array}$}} & \multirow{2}{*}{\multicolumn{2}{|c|}{$\begin{array}{l}\text { Dry weight } \% \text { of } \\
\text { total dry weight } \\
\text { relative to the } \\
\text { control }\end{array}$}} \\
\hline & \multicolumn{2}{|c|}{$\begin{array}{l}\text { Growth } \\
\text { stimulants }\end{array}$} & \multicolumn{2}{|c|}{ (g)/ plant } & \multicolumn{2}{|c|}{$\begin{array}{l}\% \text { relative to the } \\
\text { control }\end{array}$} & \multicolumn{2}{|c|}{ (g)/ plant } & \multicolumn{2}{|c|}{$\begin{array}{l}\% \text { relative to the } \\
\text { control }\end{array}$} & & & & \\
\hline & & & 2017 & 2018 & 2017 & 2018 & 2017 & 2018 & 2017 & 2018 & 2017 & 2018 & 2017 & 2018 \\
\hline With EM & & & 4.97 & 5.94 & 156.65 & 166.42 & 8.06 & 8.84 & 167.56 & 153.01 & 13.03 & 14.69 & 165.34 & 158.08 \\
\hline \multirow{9}{*}{$\begin{array}{l}\text { Without } \\
\text { EM } \\
\text { L.S.D }\end{array}$} & & & 4.27 & 4.58 & 150.89 & 155.73 & 7.48 & 8.18 & 191.44 & 181.71 & 11.62 & 12.76 & 174.23 & 167.59 \\
\hline & & & 2.36 & 2.42 & 57.80 & 57.86 & 3.62 & 3.74 & 108.11 & 108.23 & 3.72 & 3.85 & 112.66 & 112.74 \\
\hline & & trol & 3.00 & 3.23 & 100.00 & 100.00 & 4.28 & 5.14 & 100.00 & 100.00 & 7.28 & 8.37 & 100.00 & 100.00 \\
\hline & & $1 \mathrm{~m} . \mathrm{L}$ & 3.68 & 4.08 & 122.74 & 127.03 & 6.05 & 6.93 & 135.80 & 135.80 & 9.73 & 11.66 & 133.95 & 132.41 \\
\hline & S.W & $2 \mathrm{~m} . \mathrm{L}$ & 4.59 & 5.61 & 152.58 & 172.98 & 7.18 & 7.75 & 152.39 & 152.39 & 11.76 & 13.36 & 161.96 & 160.14 \\
\hline & & 2 g.L & 5.49 & 6.18 & 181.98 & 190.32 & 9.46 & 10.11 & 198.98 & 198.98 & 14.95 & 16.29 & 205.27 & 195.36 \\
\hline & UP & 4 g.L & 6.74 & 7.59 & 224.86 & 235.96 & 10.90 & 11.75 & 231.09 & 231.09 & 17.64 & 19.34 & 243.52 & 232.86 \\
\hline & & $\begin{array}{l}100 \\
\text { ppm }\end{array}$ & 3.96 & 4.36 & 131.79 & 134.85 & 7.42 & 8.09 & 159.36 & 159.36 & 11.38 & 12.45 & 156.67 & 149.72 \\
\hline & SA & $\begin{array}{l}200 \\
\text { ppm }\end{array}$ & 4.87 & 5.44 & 162.42 & 166.42 & 8.68 & 9.81 & 193.94 & 193.94 & 13.55 & 15.25 & 187.17 & 182.88 \\
\hline \multirow[t]{5}{*}{ L.S.D } & & & 2.16 & 2.26 & 57.10 & 57.22 & 3.35 & 3.42 & 107.90 & 107.96 & 3.62 & 3.66 & 112.24 & 112.30 \\
\hline & & trol & 3.17 & 3.51 & 100.00 & 100.00 & 4.71 & 5.75 & 100.00 & 100.00 & 7.88 & 9.29 & 100.00 & 100.00 \\
\hline & & $1 \mathrm{~m} . \mathrm{L}$ & 3.85 & 4.90 & 121.45 & 119.37 & 6.45 & 7.35 & 111.59 & 127.16 & 10.30 & 11.54 & 130.71 & 124.22 \\
\hline & S.W & $2 \mathrm{~m} . \mathrm{L}$ & 4.98 & 6.46 & 157.10 & 184.05 & 7.49 & 8.06 & 159.02 & 139.45 & 12.47 & 14.52 & 158.25 & 156.30 \\
\hline & & 2 g.L & 6.34 & 7.14 & 200.00 & 203.42 & 10.05 & 10.44 & 213.38 & 180.62 & 16.39 & 17.58 & 207.99 & 189.24 \\
\hline \multirow[t]{6}{*}{ With EM } & UP & 4 g.L & 7.02 & 8.04 & 221.45 & 229.06 & 11.18 & 12.20 & 237.37 & 211.07 & 18.20 & 20.24 & 230.97 & 217.87 \\
\hline & & $\begin{array}{l}100 \\
\mathrm{ppm}\end{array}$ & 4.30 & 4.87 & 135.65 & 138.75 & 7.78 & 8.30 & 165.18 & 143.60 & 12.08 & 13.17 & 153.30 & 141.77 \\
\hline & SA & $\begin{array}{l}200 \\
\mathrm{ppm}\end{array}$ & 5.10 & 6.68 & 160.88 & 190.31 & 8.78 & 9.78 & 186.41 & 169.20 & 13.88 & 16.46 & 176.14 & 177.18 \\
\hline & & trol & 2.83 & 2.94 & 100.00 & 100.00 & 3.84 & 4.50 & 100.00 & 100.00 & 6.67 & 7.44 & 100.00 & 100.00 \\
\hline & & $1 \mathrm{~m} . \mathrm{L}$ & 3.51 & 3.96 & 124.03 & 134.69 & 6.64 & 6.50 & 146.88 & 144.44 & 9.15 & 10.46 & 137.18 & 140.59 \\
\hline & S.W & $2 \mathrm{~m} . \mathrm{L}$ & 4.19 & 4.76 & 148.06 & 161.90 & 6.86 & 7.44 & 178.65 & 165.33 & 11.05 & 12.20 & 165.67 & 136.98 \\
\hline \multirow{4}{*}{$\begin{array}{l}\text { Without } \\
\text { EM }\end{array}$} & & 2 g.L & 4.64 & 5.21 & 163.96 & 177.21 & 8.78 & 9.78 & 230.99 & 217.33 & 13.51 & 14.99 & 202.55 & 201.48 \\
\hline & UP & 4 g.L & 6.46 & 7.14 & 228.27 & 242.86 & 10.62 & 11.30 & 276.56 & 251.11 & 17.08 & 18.44 & 256.07 & 247.85 \\
\hline & & ppm & 3.62 & 3.85 & 127.92 & 130.95 & 7.05 & 7.88 & 183.59 & 175.11 & 10.67 & 11.73 & 159.97 & 157.66 \\
\hline & SA & $\begin{array}{l}200 \\
\mathrm{ppm}\end{array}$ & 4.64 & 4.19 & 163.96 & 142.52 & 8.58 & 9.84 & 223.44 & 218.67 & 13.22 & 14.03 & 198.20 & 188.58 \\
\hline L.S.D & & & 2.08 & 2.11 & 56.28 & 56.34 & 3.12 & 3.22 & 107.21 & 107.22 & 3.35 & 3.43 & 111.20 & 111.42 \\
\hline
\end{tabular}

\section{II.2. Number of Flowers :}

Data in Table ( 6 ) also, indicate that different applied treatments were significantly increased number of flowers per plant during the two assigned seasons . Values were 93.75 , $95.44,86.50$, 88.70 , and $86.44,87.69$ flowers in 2017 and 2018 seasons for UP at $4 \mathrm{~g} / 1$ with EM, UP at $2 \mathrm{~g} / \mathrm{l}$ with EM and UP at $4 \mathrm{~g} / 1$ without $\mathrm{EM}$ respectively . Meanwhile values were $67.50,64.22$ and $60.41,63.55$ flowers in the 2017 and 2018 seasons for control plants by with and without EM one. Also, UP at 4g/l with EM gave the highest number of flowers during two seasons .

\section{Total fruit yield :}

As shown in Table ( 6 ), indicate that all different applied treatments exhibited significant increase of total fruits number per plants . Also, of interest to note that the treatment of U-P at $4 \mathrm{~g} / \mathrm{l}$ with $\mathrm{EM}$ and $\mathrm{UP}$ at $4 \mathrm{~g} / \mathrm{l}$ only gave the highest values in this respect . Values were $31.88,32.45$ and $29.41,30.16$ fruits with U-P at $4 \mathrm{~g} / 1$ with EM and UP at $4 \mathrm{~g} / \mathrm{l}$ only during 2017 and 2018 seasons, but 22.95 , 21.83 fruits with control plants .

As for total yield ( $\mathrm{kg} / \mathrm{plant}$ ), it could be noticed that different applied treatments were significantly increased total fruit yield per plant during two seasons . Also , UP at $4 \mathrm{~g} / \mathrm{l}$ with EM was gave the highest increase of total yield per plant when compared with control plants .

Moreover, the obtained high number of yielded ripened sweet pepper fruits was also accompanied with high significant increase in their weight ( $\mathrm{kg} /$ plant ). 
Table 6. Effect of EM, growth stimulants and their interaction on flowering and total yield of sweet pepper transplanting during 2017-2018 seasons.

\begin{tabular}{|c|c|c|c|c|c|c|c|c|c|c|c|c|}
\hline \multicolumn{3}{|c|}{$\begin{array}{l}\text { Growth character } \\
\text { Treatments }\end{array}$} & \multicolumn{2}{|c|}{$\begin{array}{c}\text { Start of flower } \\
\text { anthesis } \\
\text { (days) }\end{array}$} & \multicolumn{2}{|c|}{$\begin{array}{c}\text { No. of flowers / } \\
\text { plant }\end{array}$} & \multicolumn{2}{|c|}{$\begin{array}{l}\text { Total fruits } \\
\text { (No. / plant) }\end{array}$} & \multicolumn{2}{|c|}{$\begin{array}{l}\text { Total yield } \\
\text { (kg/plant) }\end{array}$} & \multicolumn{2}{|c|}{$\begin{array}{l}\text { Relative total } \\
\text { yield } \\
(\%)\end{array}$} \\
\hline \multirow{2}{*}{ EM } & \multirow{2}{*}{\multicolumn{2}{|c|}{$\begin{array}{c}\text { Growth } \\
\text { stimulants }\end{array}$}} & & & & & & & & & & \\
\hline & & & 2017 & 2018 & 2017 & 2018 & 2017 & 2018 & 2017 & 2018 & 2017 & 2018 \\
\hline \multirow{10}{*}{$\begin{array}{c}\text { With EM } \\
\text { Without } \\
\text { EM } \\
\text { L.S.D } \\
\end{array}$} & & & 52.00 & $\mathbf{5 0 . 5 7}$ & 77.47 & 78.70 & 26.34 & 26.76 & 1099.73 & 1165.66 & 181.51 & 189.81 \\
\hline & & & $\mathbf{5 8 . 7 0}$ & 57.57 & 71.79 & 72.84 & 24.41 & 24.76 & 981.58 & 1019.04 & 183.45 & 173.88 \\
\hline & & & 1.43 & 1.46 & 2.75 & 2.78 & 1.42 & 1.46 & & & & \\
\hline & & rol & 65.45 & 66.28 & 63.96 & 63.89 & 21.75 & 21.72 & 570.48 & 600.07 & 100.00 & 100.00 \\
\hline & & $\begin{array}{c}\mathbf{1} \\
\mathbf{m} . \mathbf{L}\end{array}$ & 55.80 & 55.25 & 66.45 & 66.60 & 22.59 & 22.64 & 771.51 & 824.25 & 134.70 & 136.99 \\
\hline & S.W & $\begin{array}{c}2 \\
\mathbf{m} . \mathrm{L}\end{array}$ & 57.10 & 57.58 & 70.09 & 71.48 & 23.83 & 22.64 & 890.93 & 957.44 & 156.19 & 159.42 \\
\hline & & 2 g.L & 47.31 & 48.10 & 84.55 & 86.25 & 28.75 & 29.33 & 1409.47 & 1437.35 & 247.96 & 239.30 \\
\hline & UP & 4 g.L & 48.30 & 48.41 & 90.10 & 91.57 & 30.63 & 31.13 & 1490.43 & 1565.49 & 261.27 & 260.56 \\
\hline & & $\begin{array}{c}100 \\
\text { ppm }\end{array}$ & 52.05 & 50.19 & 72.50 & 74.53 & 24.65 & 25.34 & 1036.81 & 1098.35 & 181.93 & 182.92 \\
\hline & SA & $\begin{array}{c}200 \\
\text { ppm }\end{array}$ & 52.45 & 53.02 & 74.76 & 76.18 & 25.42 & 25.90 & 1115.01 & 1163.51 & 195.30 & 193.71 \\
\hline \multirow[t]{4}{*}{ L.S.D } & & & 1.38 & 1.41 & 2.69 & 2.71 & 1.36 & 1.38 & & & & \\
\hline & & & 64.20 & 65.40 & 67.50 & 64.22 & 22.95 & 21.83 & 605.88 & 614.08 & 100.00 & 100.00 \\
\hline & & $\begin{array}{c}\mathbf{1} \\
\mathbf{m} . \mathrm{L}\end{array}$ & 55.40 & 45.28 & 70.20 & 71.50 & 23.87 & 24.31 & 868.87 & 922.81 & 143.41 & 150.16 \\
\hline & S.W & $\begin{array}{c}2 \\
\text { m.L }\end{array}$ & 56.40 & 56.66 & 71.74 & 73.80 & 24.39 & 25.09 & 944.14 & 1015.14 & 155.83 & 165.31 \\
\hline \multirow[t]{7}{*}{ With EM } & & 2 g.L & 46.40 & 47.30 & 86.50 & 88.70 & 29.41 & 30.16 & 1415.21 & 1529.11 & 233.58 & 249.01 \\
\hline & UP & 4 g.L & 46.20 & 46.15 & 93.75 & 95.44 & 31.88 & 32.45 & 1581.89 & 1686.10 & 261.69 & 274.57 \\
\hline & & $\begin{array}{c}100 \\
\text { ppm }\end{array}$ & 45.20 & 42.18 & 74.45 & 77.56 & 25.31 & 26.37 & 1084.03 & 1155.01 & 178.92 & 188.09 \\
\hline & SA & $\begin{array}{c}200 \\
\text { ppm }\end{array}$ & 50.20 & 51.70 & 78.12 & 79.70 & 26.56 & 27.10 & 1198.12 & 1237.39 & 197.75 & 201.50 \\
\hline & & & 66.70 & 76.15 & 60.41 & 63.55 & 20.54 & 21.61 & $\mathbf{5 3 5 . 0 7}$ & 586.06 & 100.00 & 100.00 \\
\hline & & $\begin{array}{c}\mathbf{1} \\
\mathbf{m} . \mathrm{L}\end{array}$ & 56.20 & 56.22 & 62.70 & 61.70 & 21.32 & 20.98 & 674.14 & 725.69 & 125.99 & 123.83 \\
\hline & S.W & $\begin{array}{c}2 \\
\mathbf{m} . \mathrm{L}\end{array}$ & 75.80 & 58.50 & 68.44 & 69.15 & 23.27 & 23.51 & 837.72 & 899.73 & 156.56 & 153.52 \\
\hline \multirow{4}{*}{$\begin{array}{c}\text { Without } \\
\text { EM }\end{array}$} & & 2 g.L & 48.22 & 48.90 & 82.60 & 83.86 & 28.08 & 28.49 & 1403.72 & 1345.58 & 262.34 & 229.59 \\
\hline & $\mathbf{U P}$ & 4 g.L & 50.40 & 50.66 & 86.44 & 87.69 & 29.39 & 29.81 & 1398.96 & 1444.89 & 261.45 & 246.54 \\
\hline & & $\begin{array}{c}100 \\
\text { ppm }\end{array}$ & 58.90 & 58.20 & 70.55 & 71.50 & 23.99 & 24.31 & 989.58 & 1041.68 & 184.94 & 177.74 \\
\hline & SA & $\begin{array}{c}200 \\
\text { ppm } \\
\end{array}$ & 54.70 & 54.33 & 71.40 & 72.45 & 24.28 & 24.63 & 1031.90 & 1089.63 & 192.58 & 185.92 \\
\hline L.S.D & & & 1.23 & 1.31 & 2.60 & 2.66 & 1.31 & 1.35 & & & & \\
\hline
\end{tabular}

Fruit quality :

\section{Fruit characteristics :}

Data in Table ( 7 ) clearly indicate that different applied treatments increased fruit fresh weight of sweet pepper during two seasons . Also, UP at $4 \mathrm{~g} / \mathrm{l}$ with E.M gave the highest increase of fruit fresh weight followed by UP at $4 \mathrm{~g} / \mathrm{l}$ only .

On the other hand, fruit dimensions, i.e. , length and diameter were variously responded. In this respect, fruit . length was insignificant increase by most treatments during two seasons .

Also , fruit diameter was increased with different applied treatments but UP at $4 \mathrm{~g} / \mathrm{l}$ with EM gave the highest increase in this respect during two seasons .
In this respect, it could be concluded that insignificant increase of fruit length and insignificant increase of its diameter being related with alternation in hormone profile. Since, U-P increased cytokinins concentration in shoots of sweet pepper plants as well mentioned later. Cytokinins hen been reported not only to increase the wide growth on the account of longitudinal one but also to make fruits and other storage organs very active and strong sinks ( Hopkims,1995 ) .

Therefore, fruit shape index, as shown in Table ( 7 ) considered as a light view for different effects of used treatments upon fruit characteristics . 
Table 7. Effect of EM, growth stimulants and their interaction on fruit characteristics of sweet pepper during 2017-2018 seasons

\begin{tabular}{|c|c|c|c|c|c|c|c|c|c|c|}
\hline \multirow{2}{*}{$\begin{array}{l}\text { Growth character } \\
\text { Treatments }\end{array}$} & & & \multirow{2}{*}{\multicolumn{2}{|c|}{$\begin{array}{l}\text { Fruit fresh weight } \\
\qquad(\mathrm{g}) / \text { fruit }\end{array}$}} & \multicolumn{4}{|c|}{ Fruit dimensions } & \multirow{2}{*}{\multicolumn{2}{|c|}{$\begin{array}{l}\text { Fruit shape index } \\
(\mathrm{L} / \mathrm{D})^{*}\end{array}$}} \\
\hline & & & & & \multicolumn{2}{|c|}{ Length (cm) } & \multicolumn{2}{|c|}{ Diameter (cm) } & & \\
\hline EM & \multicolumn{2}{|c|}{$\begin{array}{c}\text { Growth } \\
\text { Stimulants }\end{array}$} & 2017 & 2018 & 2017 & 2018 & 2017 & 2018 & 2017 & 2018 \\
\hline \multirow{9}{*}{$\begin{array}{c}\text { With EM } \\
\text { Without EM } \\
\text { L.S.D }\end{array}$} & & & 41.03 & 42.67 & 4.94 & 5.06 & 3.77 & 4.21 & 1.33 & 1.21 \\
\hline & & & 39.29 & 40.39 & 5.17 & 5.41 & 3.24 & 3.74 & 1.63 & 1.47 \\
\hline & & rol & 26.23 & 27.63 & 4.40 & $\mathbf{3 . 5 0}$ & 2.70 & 2.70 & 1.63 & 1.30 \\
\hline & & $1 \mathrm{~m} . \mathrm{L}$ & 34.01 & 36.14 & 4.80 & 5.00 & 3.50 & 3.90 & 1.37 & 1.28 \\
\hline & S.W & 2 m.L & 37.36 & 39.37 & 5.30 & 5.80 & 3.50 & 4.10 & 1.51 & 1.41 \\
\hline & & 2 g.L & 47.06 & 48.97 & 4.70 & 5.00 & 3.90 & 4.40 & 1.21 & 1.27 \\
\hline & UP & 4 g.L & 48.61 & 50.22 & 5.70 & 6.10 & 4.50 & 5.30 & 1.27 & 1.15 \\
\hline & & $\begin{array}{c}100 \\
\text { ppm }\end{array}$ & 42.04 & 43.33 & 5.00 & 5.40 & 3.30 & 3.80 & 1.51 & 1.42 \\
\hline & $\mathbf{S A}$ & $\begin{array}{c}200 \\
\text { ppm }\end{array}$ & 43.81 & 44.95 & 5.70 & 5.40 & 3.30 & 3.80 & 1.73 & 1.42 \\
\hline \multicolumn{11}{|l|}{ L.S.D } \\
\hline \multirow{7}{*}{ With EM } & \multicolumn{2}{|c|}{ Control } & 26.40 & 28.13 & 4.40 & 3.60 & 2.90 & 3.10 & 1.52 & 1.16 \\
\hline & & $1 \mathrm{~m} . \mathrm{L}$ & 36.40 & 37.96 & 4.30 & 4.50 & 3.80 & 4.10 & 1.13 & 1.10 \\
\hline & S.W & $2 \mathrm{~m} . \mathrm{L}$ & 38.71 & 40.46 & 4.80 & 5.40 & 3.70 & 4.20 & 1.30 & 1.29 \\
\hline & & 2 g.L & 48.12 & 50.70 & 4.70 & 5.50 & 4.20 & 4.60 & 1.12 & 1.20 \\
\hline & $\mathbf{U P}$ & 4 g.L & 49.62 & 51.96 & 5.60 & 6.10 & 4.60 & $\mathbf{5 . 5 0}$ & 1.22 & 1.11 \\
\hline & & $\begin{array}{c}100 \\
\text { ppm }\end{array}$ & 42.83 & 43.80 & 5.50 & 5.40 & 3.60 & 3.90 & 1.53 & 1.38 \\
\hline & $\mathbf{S A}$ & $\begin{array}{c}200 \\
\text { ppm }\end{array}$ & 45.11 & 45.66 & 5.30 & 4.90 & 3.60 & 4.10 & 1.47 & 1.20 \\
\hline \multirow{7}{*}{ Without EM } & \multicolumn{2}{|c|}{ Control } & 26.05 & 27.12 & 4.30 & 3.40 & 2.40 & 2.30 & 1.79 & 1.48 \\
\hline & & $1 \mathrm{~m} . \mathrm{L}$ & 31.62 & 34.59 & 5.20 & 5.40 & 3.10 & 3.60 & 1.68 & 1.50 \\
\hline & S.W & $2 \mathrm{~m} . \mathrm{L}$ & 36.00 & 38.27 & 5.70 & 6.10 & 3.30 & 3.90 & 1.73 & 1.56 \\
\hline & & 2 g.L & 49.99 & 47.23 & 4.70 & 5.60 & 3.60 & 4.20 & 1.31 & 1.33 \\
\hline & $\mathbf{U P}$ & 4 g.L & 47.60 & 48.47 & 5.80 & 6.10 & 4.40 & 5.10 & 1.32 & 1.20 \\
\hline & & $\begin{array}{c}100 \\
\text { ppm }\end{array}$ & 41.25 & 42.85 & 4.40 & 5.40 & 3.00 & 3.60 & 1.47 & 1.50 \\
\hline & $\mathbf{S A}$ & $\begin{array}{c}200 \\
\text { ppm }\end{array}$ & 42.50 & 44.24 & 6.10 & 5.90 & 2.90 & 3.50 & 2.10 & 1.69 \\
\hline
\end{tabular}

\section{References}

Black, C.A.; Evans, D.O.; Ensminger, LE.; White, J.L.; Clark, F.E. and Dinauer ,R.C. (1982): Methods of soil analysis. part 2. Chemical and microbiological properties. 2nd ed. Soil Sci.,Soc. of Am. Inc. Publ., Madison, Wisconsin, U. S.A.

Cakmak , T . and Marschner , H . ( 1992 ) : Magnesium deficiency and high light intensity enhance activities of superoxide dismutase and ascorbate peroxidase and glutathione reductase in bean leaves. Plant Physiol . 911222 - 1227

Derieux, M. ; Kerrest, R. and Montalanty, Y. (1973): Etude de la surface foliaive et de lactivite photosynthetique chez kulkues hybrids de mais. Ann. Amelior plants , 23:95-107.

Dickinson , C . D . ; Altabella , T . and Chrispeel , M . J . ( 1991 ) : Slow - growth phenotype of transgenic tomato expressing apoplastic invertase . Plant Physiol . $95: 420-425$.

Hall, D.O.; Scurlock, J. M.O.; BolharNordenkampl, H.R.; Leegood, R.C. and Long S.P. (1993): photosynthesis and production in a changing environment .A field and laboratory manual. 3-Growth analysis. London. Glasgow New York. Tokyo. Melbourne. Madras., PP.39.

Herrera, R. M. H.; Ruvalcaba, F. S.; Lopez, M. A. R.; Norrie ,J. and Carmona ,G. H.(2014): Effect of liquid seaweed extracts on growth of tomato seedlings (Solanum lycopersicum L.) J. Appl. Phycol., 26(1):619-628.

Horvath , E . and Szalai , G . Janda , T . ( 2007 ) : Induction of abiotic stress tolerance by salicylic acid signaling . I . Plant Growth Regul . . ( 26 ) : 290300.

Jackson, M.L. (1973): Soil Chemical Analysis. Printice-Hall of India. Privat Limited, New Delhi.

Janda, T . : Szalai , G . : Leskó, K . : Yordanova, R : Apostol . S . and Popova , ( 2007 ) : Factor contributing to enhanced freeing tolerance in when during frost hardening in the light. Phytochemistry $68: 1674-1682$

Lindani, N. and Bvenura, C.(2012): Effects of the integrated use of effective micro-organisms, compost and mineral fertilizer on greenhousegrown tomato. African J. of Plant Sci., 6(3):120124. 
Mackerise, B . O . ; Bowley , S . R . : Harjanio . E and Lepnnce , O . ( 1996 ) : Water deficit tolerance and field performances of transgenic alfalfa over expressing superoxide dismutase . Plant Physiol . 111 : 1170 - 1181 .

Mady, M . A . ( 2014 ) : Inducing cold tolerability in squash ( Cucurbita pepo . L . ) plant by using salicylic acid and chelated calcium application / International J . Agric . Sei and Res . ( IJASR ), 4 ( 4 ) : 9 - 24

Radford, P.J. (1967): Growth analysis formulae their use and abuse. Crop. Sci., 7:171-176.

Rosalba, M.H.; Fernando, S.R. and Jeffrey, G.H.(2013): Effect of liquid seaweed extract on growth of tomato seedlings. J. Appl.Phycol., 2: 2129.

Snedecor, G.W. and Cochran, W.G.(1991): Statistical methods. $8^{\text {th }}$ Ed., Iowa state Univ. press, Iowa, USA.
Sutharsan, S.; Nishanthi, S. and Srikrishnah ,S. (2014): Effects of foliar application of seaweed (Sargassum crassifolium) liquid extract on the performance of Lycopersicon esculentum Mill. in sandy regosol of Batticaloa district Sri Lanka. American-Eurasian J. Agric. \& Environ. Sci.,14(12):1386-1396.

Wien , H . C . ( 1997 ): The cucurbits : cucumber, melon, squash and pumpkin in the Physiology of vegetable crops . CAB International, HC Wien ( ed . ) . pp . 345 - 386

Yu , K . Y ., Park, M . R .; Mohanty , B . : Herath , V . ; Xu , F .; Mauleon , R .; Wijaya , E . : Bajie . V . B . ; Brusewich, R . and Reyes , B . G . ( 2010 ) :Transcriptional regulatory network triggered by oxidative signals configures the early response mechanisms of japonica rice to chilling stress . BMC Plant Biol . 10 : 16 .

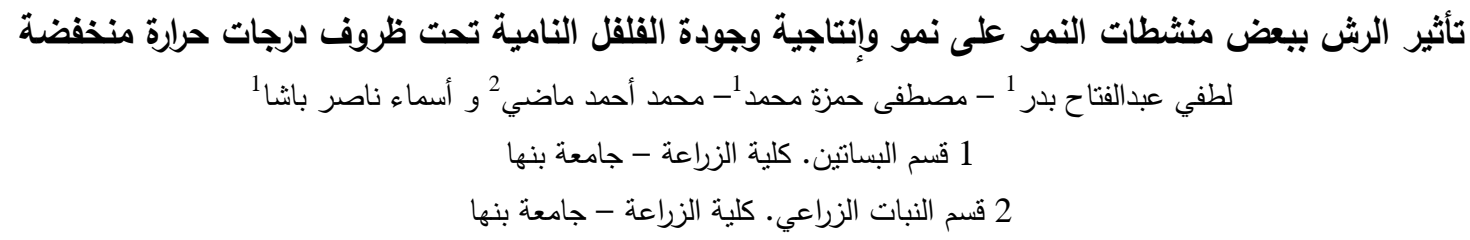

اجريت تجربتين حقليتين خلال موسم الصيف المبكر لعامي 2017 و 2018 في مزرعة قسم البساتين ,كلية الزراعة بمشتهر رامعة بنها, محافظة

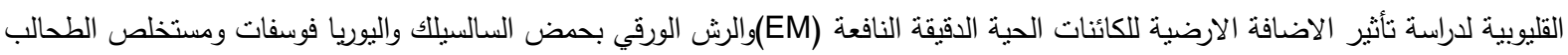
البحرية كلآ علي حدا والتفاعل بينهما علي صفات النمو الخضري وصفات البناء الضوئي (كلوروفيل ا بب والكاروتين ) والتركيب الكيميائي والدحصول

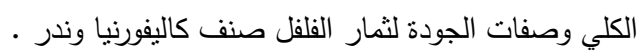
وقد اشتملت التجربة علي 14 معاملة وهي كما يلي :تأثير الكائنات الحية الدقيقة النافعة (EM) بتركيز 100 مل/تنز ,مستخلص الطحالب البحرية

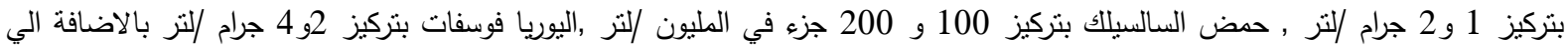

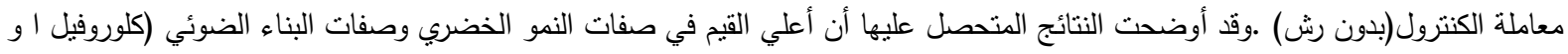
ب والكاروتين )والتركيب الكيميائي والمحصول الكلي وصفات الجودة لثمار الفلفل تم الحصول عليها نتيجة اضافة الكائنات الحية الدقيقة النافعة

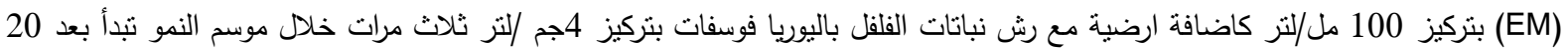

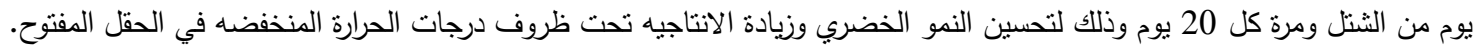

